\title{
A reassessment of Mappia (Icacinaceae) taxonomy using environmental data
}

\section{Una reevaluación de la taxonomía de Mappia (Icacinaceae) utilizando datos ambientales}

\section{Acta Botanica Mexicana}

\author{
Rodrigo Duno De Stefano' (1) , Israel Loera ${ }^{2}$ (d) , Diego F. Angulo 3,4 (c)
}

\begin{abstract}
:
Background and Aims: Mappia (Icacinaceae) is a genus comprising four species inhabiting Mesoamerica and the Greater Antilles. In the most recent phylogenetic analysis based on morphological data, three species, representing a continental clade (Mappia longipes, M. mexicana and M. multiflora) sister to the Antillean species M. racemosa, were supported. Our aims in this study were to evaluate whether environmental data support the previous hypothesis in Mappia entities.

Methods: In this study, we use ecological niche analysis (environmental niche modeling and niche divergence/conservatism tests) and multivariate analysis of variance (MANOVA) to test the previous morphological hypothesis at species and infraspecific level.

Key results: Ecological differentiation between M. multiflora distributed from southeast Mexico to Costa Rica and M. racemosa occurring in Cuba, Jamaica, and Puerto Rico (Greater Antilles) was found, but not between the infraspecific taxa within the Antilles (M. racemosa var. brachycarpa, and M. racemosa var. racemosa).

Conclusions: Our study brings an important signal of the ecological divergence between closely related species, but with disjunct patterns of distribution.

Key words: Central America, environmental niche modeling, Greater Antilles, Neotropics.

\section{Resumen:}

Antecedentes y Objetivos: Mappia (Icacinaceae) es un género de cuatro especies que habitan Mesoamérica y las Antillas Mayores. El más reciente análisis filogenético del género basado en datos morfológicos apoyó la existencia de un clado continental formado por Mappia longipes, M. mexicana y M. multiflora como grupo hermano de $M$. racemosa que se distribuye en las Antillas. El objetivo fue evaluar si datos ambientales soportan las hipótesis previas propuestas para las entidades de Mappia.

Métodos: Se realizaron análisis de nicho ecológico (modelado de nicho ambiental y pruebas de divergencia/conservadurismo de nicho) y de varianza multivariado (MANOVA) para evaluar si existen otras líneas de evidencia que respalden la hipótesis morfológica previa a nivel de especie e infraespecífico.

Resultados clave: Se encontró una diferenciación ecológica entre M. multiflora (sureste de México a Costa Rica) y M. racemosa (Cuba, Jamaica y Puerto Rico (Antillas Mayores)), pero no entre los taxones infraespecíficos de las Antillas ( $M$. racemosa var. brachycarpa y M. racemosa var. racemosa). Conclusiones: Nuestro estudio aporta una importante señal de la divergencia ecológica entre especies cercanamente emparentadas, pero con patrones de distribución disyunta.
\end{abstract}

Palabras clave: Antillas Mayores, Centro América, modelado de nicho ecológico, Neotrópico.

\footnotetext{
${ }^{1}$ Centro de Investigación Científica de Yucatán, A.C. (CICY), Herbario CICY, Calle 43 No. 130, Col. Chuburná de Hidalgo, 97200 Mérida, Yucatán, México. ${ }^{2}$ Harvard University, Department of Organismic and Evolutionary Biology, 22 Divinity Avenue, 02138 Cambridge, Massachusetts, USA.

${ }^{3}$ Universidad Autónoma de Yucatán, Departamento de Botánica, Carretera Mérida-Xmatkuil, km 15.5, 97000 Mérida, Yucatán, México.

${ }^{4}$ Author for correspondence: diangulo@gmail.com
}

Received: April 23, 2020.

Reviewed: May 18, 2020.

Accepted by Marie-Stéphanie Samain: July 16, 2020

Published Online first: August 17, 2020.

Published: Acta Botanica Mexicana 127(2020).

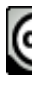

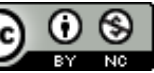
BY NC

This is an open access article under the Creative Commons 4.0 Attribution-Non icence (CC BY-NC 4.0 Internacional).
To cite as: Duno de Stefano, R., I. Loera, and D. F. Angulo. 2020. A reassessment of Mappia (Icacinaceae) taxonomy using environmental data. Acta Botanica Mexicana 127: e1716. DOI: 10.21829/ abm127.2020.1716 


\section{Introduction}

The genus Mappia Jacq. (Icacinaceae) was described in 1797 by Nikolaus Joseph Jacquin and was forgotten until 1852, when John Miers assigned many new species to this genus (Howard, 1942). Baehni (1936) conducted a taxonomic review of Mappia and segregated the Asiatic species of Mappia into a new genus, Neoleretia Baehni (=Nothapodytes Blume). To date, Mappia consists of four species found in Mexico, Central America, and the Greater Antilles (Fig. 1). The species are trees or shrubs characterized by leaves without stipules, domatia on the abaxial surface of the leaves, malphigiaceous hairs on vegetative and floral structures, axillary inflorescences, bracts and bracteoles absent, pentamerous flowers, petals bearded on their inner surface and ovary surrounded by a disc. The group is particularly interesting because all the species, and especially Mappia mexicana B.L. Rob. \& Greenm. and M. longipes Lundell, are notably rare (small distribution range and few individuals), hence, a better understanding of the Mappia circumscription might provide important insights for its conservation.
On the one hand, Mappia mexicana and M. longipes are well-distinguished species based on their morphology and distribution. Mappia mexicana has small obovate leaves with a rounded apex (vs. acute to acuminate leaves in all other species) and a completely glabrous flower (vs. pubescent flowers in all other species) (Robinson and Greenman, 1895). It grows in thorny scrub and thorny forest in the border region between the states of Tamaulipas and San Luis Potosí in northeastern Mexico. Mappia longipes has a long floral peduncle ( $9 \mathrm{~cm}$ long) vs. ca. $3 \mathrm{~cm}$ long in all the other species (Lundell, 1942). It grows at $1300 \mathrm{~m}$ elevation in the cloud forest of Chiapas (southeastern Mexico) (Lundell, 1942).

On the other hand, Mappia racemosa Jacq. has elliptic or obovate leaves, a short peduncle (ca. $3 \mathrm{~cm}$ long) and a completely pubescent flower. Moreover, it has a larger distribution area, occurring in dry forest in Cuba, Jamaica, and Puerto Rico (Duno de Stefano and Angulo, 2010). Mappia racemosa has two infraspecific taxa; $M$. racemosa var. brachycarpa Griseb., and M. racemosa var. racemosa with few morphological differences; number of secondary

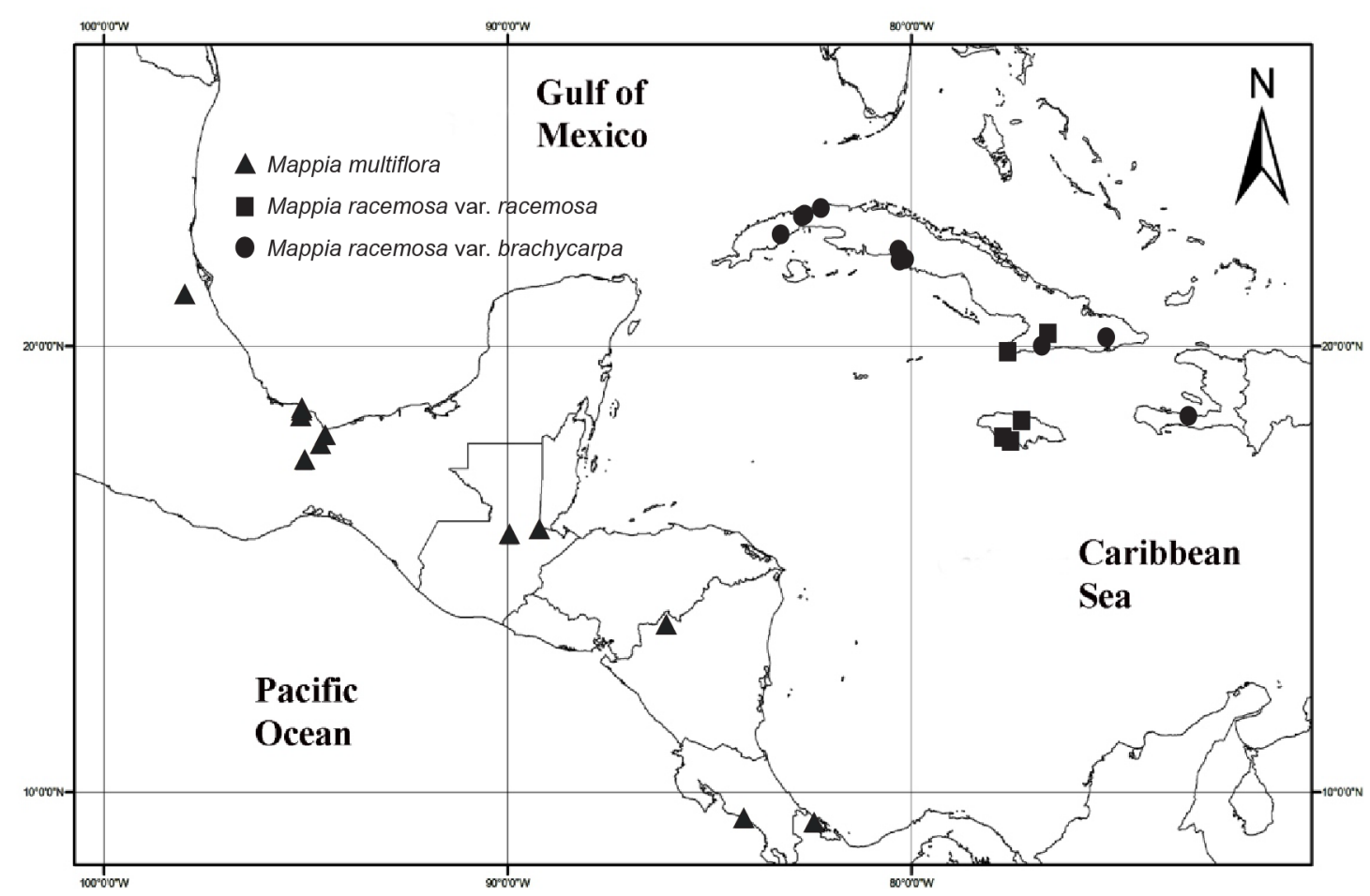

Figure 1: Geographic distribution of Mappia multiflora Lundell, Mappia racemosa Jacq. var. brachycarpa Griseb., and Mappia racemosa Jacq. var. racemosa. 
veins (7-13 vs. 7-9), apex of the leaves (acute vs. acuminate), fruit size $(14-22 \times 1-16 \times 1-13$ vs. $12-17 \times 1-11 \times 08$ $\mathrm{mm}$ ) (Angulo et al., 2013). The most important morphological difference is the fruit. The mesocarp can be fleshy or not (Howard, 1942). However, this trait is highly variable within Mappia species (Angulo, 2006). Finally, Mappia multiflora Lundell occurs in the dry forest of Mexico to Costa Rica and has larger leaves than $M$. racemosa. Both Mappia racemosa and $M$. multiflora are morphologically similar, and have been confused throughout their distribution area. Mappia multiflora has longer leaves, 7 to $29.5 \mathrm{~cm}$ long (vs. 4.5 to 18 $\mathrm{cm}$ ), secondary veins conspicuous on the abaxial surface of the leaves (vs. secondary veins inconspicuous), and leaves of the herbarium specimens dark green (vs. green-brown) (Angulo et al., 2013).

Previous phylogenetic analyses with a molecular plastid marker (ndhF) and morphological data have been realized within Mappia and related groups (Angulo et al., 2013). The results suggest that within Mappia, there is morphological support for a continental clade ( $M$. longipes, M. mexicana and M. multiflora) sister to the Antillean species $M$. racemosa. However, these relationships were not resolved in the molecular analyses or in the combined molecular-morphological analyses (Angulo et al., 2013). Two fundamental reasons are responsible for these results: insufficient data and low phylogenetic signal of the marker used (Wortley et al., 2005).

In addition to traditional morphological and/or molecular differences (Wiens and Penkrot, 2002; Sites and Marshal, 2003, 2004), the inclusion of geographic (Barraclough et al., 1998; Schneider and Moritz, 1998), and ecological data (Anderson et al., 2002a, b; Johnson and Cicero, 2002; Martínez-Gordillo et al., 2010) has given an important new impulse to assessing the status and distribution of poorly know taxa and species conservation (Gaubert et al., 2006).

In recent years there has been a substantial increase in the digitization of natural history collections, which has contributed to the integration of this information in global repositories (e.g. REMIB, 2019; GBIF, 2019). Parallel to this there has been a considerable development of global environmental data at fine scale resolutions (e.g. WorldClim, (Hijmans et al., 2005); SoilGrids (Hengl et al., 2017)). The integration of these data, although with potential caveats, has contributed to important insights in the biodiversity distribution around the globe, as well to understanding the role of ecological divergence on speciation.

Ecological divergence is one of the most widely reported processes that promotes diversification in natural populations (e.g., Jansson and Dynesius, 2002; Barnosky, 2005; Mittelbach et al., 2007) and has recently received much attention (Hua and Wiens, 2013).

Environmental niche modeling is a method that uses occurrence data in conjunction with environmental data to make a correlative model of the environmental conditions that meet a species' ecological requirements and predict the relative suitability of habitat (Warren and Seifert, 2011). These methods have now been applied to evaluate ecological divergence (Rissler and Apodaca, 2007; Murienne et al., 2009) and are widely used in diverse biodiversity studies (e.g. predicting species' geographic potential (Peterson, 2003)); and species' potential distributions under different climatic conditions (Martínez-Meyer et al., 2004).

Niche conservatism can be defined as the tendency for many ecological traits to remain similar over time. Outside the niche, individuals are not expected to leave descendants, nor populations to persist, nor clades to endure and proliferate (Wiens et al., 2010). However, a niche shift is possible, and a new lineage can utilize a new diet, host, habitat, and climatic regime. This adaptative divergence ensures not only the occupancy of two or more niches, but also reproductive isolation (revised in Wiens and Graham, 2005). Adaptative divergence in most species is more likely to occur at the level of local population as has been demonstrated in a fen orchid (Vanden Broeck et al., 2014). At local level, ecological divergence could be related with shifts in the pollinator's assembly that have also contributed to maintaining genetic isolation as has been observed in other species (Angulo et al., 2014a, b). Additionally, different climate habitats could act as a barrier to gene flow influencing reproductive isolation, and minimizing connectivity among populations (e.g., Kozak and Wiens, 2007; Sobel et al., 2010). A divergent niche among close relatives has been detected in other plants as a response to different factors such as drought stress (Mimulus L.; Peterson et al., 2013), salt tolerance (Mimulus 
guttatus DC.; Lowry et al., 2008), and host plant adaptation with the beetle Neochlamisus Karren (Funk et al., 2011).

Here, we used ecological niche analysis (environmental niche modeling and niche divergence/ conservatism tests) and multivariate analysis of variance (MANOVA) to evaluate whether ecological factors support previous taxonomic conclusions based on morphology (Angulo et al., 2013), which suggests that Mappia multiflora (continental), and Mappia racemosa (Antillean) are morphologically different species with different distribution areas. In the case of the Antilles, both intraspecific taxa proposed by Howard (1942) are morphologically identical with a similar distribution area.

\section{Materials and Methods}

\section{Sample collection}

One hundred specimens of Mappia were studied from sixteen herbaria: $\mathrm{BM}, \mathrm{CICY}, \mathrm{F}, \mathrm{G}, \mathrm{GH}, \mathrm{GOET}, \mathrm{K}, \mathrm{LL}, \mathrm{MA}$, MEXU, MO, NY, P, US, TEX and XAL (acronyms according to Thiers, 2020). The species delimitation of Mappia racemosa and M. multiflora used in this study was based on Angulo et al. (2013). In order to test the infraspecific taxa recognition of Mappia racemosa, we analyzed only the original label determined by Howard (1942) as M. racemosa var. brachycarpa and $M$. racemosa var. racemosa.

Rare species, those with either a small range or a low abundance (Rabinowitz, 1981), represent the vast majority of species (Longino et al., 2002) and are consequently represented by few samples in natural history collections, the primary source of distributional data (van Proosdij et al., 2016). This is the case of the genus Mappia, as the analysis was originally intended for the whole genus. However, two species are poorly known: Mappia longipes and $M$. mexicana are only recorded from one and four collections, respectively, and were excluded from the analyses. Of the reviewed herbarium specimens, we only used those with georeferences of Mappia multiflora (33 specimens) and $M$. racemosa (36 specimens; 12 for $M$. racemosa var. racemosa and 24 for $M$. racemosa var. brachycarpa).

\section{Environmental niche modeling}

Environmental niche modeling (ENM) was used in order to visualize whether the climatic niches of different taxonomic entities are inter-predictable; we estimated environmental niche models for each entity. We employed the MaxEnt software (Phillips et al., 2006) since it offers many advantages, and few drawbacks as compared with other modeling methods: (1) it requires only presence data, together with environmental information, (2) it can utilize both continuous and categorical data, including interactions between different variables, (3) it possesses efficient deterministic algorithms that guarantee to converge to the maximum entropy probability distribution, (4) the MaxEnt probability distribution has a concise mathematical definition, and is therefore amenable to analysis (Phillips et al., 2006). Moreover, MaxEnt has shown good performance with small or incomplete data sets and still produces near maximum accuracy levels (Hernandez et al., 2006).

ENMs were performed using standard bioclimatic variables obtained from the WorldClim 1.4 database (Hijmans et al., 2005) with $\sim 1 \mathrm{~km}^{2}$ resolution. We performed a correlation analysis using the $\mathrm{R}$ statistical software ( $R$ Core Team, 2017) and selected nine not correlated variables (pairwise $r<0.7$ based on all sample locations) (Peterson, 2007; Nakazato et al., 2010). These variables were derived from temperature and precipitation (Table 1). Parameters for all the MaxEnt analyses were as following: convergence threshold $=10^{-5}$, maximum iterations $=1000$, regularization multiplier $=1$, in addition to other default modeling parameters. Binary maps (predicted presence or absence) were created from the MaxEnt-generated niche distribution models using a threshold value of $>0.5$. Model performance was evaluated by the area under the receiver-operating characteristic curve (AUC) and the lowest presence threshold value (LPT, Peterson et al., 2007; Lobo et al., 2008). AUC scores were calculated using training data (Fielding and Bell, 1997).

\section{Ecological differentiation between species}

Ecological differentiation was evaluated with niche divergence/conservatism tests using environmental data and taxa occurrence points. These tests were run following a multivariate analysis-based methodology developed by McCormack et al. (2010), and employing the same environmental variables used in environmental niche modeling (see above). For each entity, bioclimatic data 
Table 1: Bioclimatic parameters, sets used for ecological niche model (ENM) generation and climatic PCA. Mappia multiflora Lundell (MM), M. racemosa Jacq. var. racemosa (MRR), and M. racemosa Jacq. var. brachycarpa Griseb. (MRB). Temperature in ${ }^{\circ} \mathrm{C}$ and precipitation in mm.

\begin{tabular}{lccc}
\hline Climate variable & MM & MRR & MRB \\
\hline Isothermality (Bio3) & 6.2 & 6.84 & 6.4 \\
Max Temperature of Warmest Month (Bio5) & 32.2 & 30.1 & 31.1 \\
Min Temperature of Coldest Month (Bio6) & 17.1 & 17.7 & 15.9 \\
Temperature Annual Range (Bio7) & 15.1 & 12.4 & 15.2 \\
Mean Temperature of Wettest Quarter (Bio8) & 25.6 & 25.1 & 25.6 \\
Precipitation of Driest Month (Bio14) & 5.8 & 4.4 & 3.4 \\
Precipitation Seasonality (Bio15) & 6.2 & 5.2 & 5.5 \\
Precipitation of Wettest Quarter (Bio16) & 116.1 & 60.7 & 56.5 \\
Precipitation of Warmest Quarter (Bio18) & 63.7 & 45.5 & 52.8 \\
\hline
\end{tabular}

for the actual occurrence points were extracted, and 1000 points were taken from the background environmental area (based on polygons drawn around the occurrence points). A principal component analysis (PCA) was run using PAST 1.99 (Hammer et al., 2001), and the first six axes, which explained over $95 \%$ of the total variance, were used to test for niche divergence/conservatism. Each axis's niche was tested against a null model of background divergence by comparing the observed difference in mean niche values on a given axis to the difference in mean background values between paired comparisons. Significance was assessed with 1000 jackknife replicates of the mean background values. A 95\% significance level was applied for null model rejection. All these analyses were performed in STATA v. 11.0 (StataCorp., 2009).

Finally, a conventional multivariate analysis of variance (MANOVA) was performed in SPSS v. 19.0 (IBM, 2010), using environmental variables for each species pair to determine whether the observed environmental conditions differed significantly. The F-statistic was reported, and a test of between-subject effects was run to determine which PCs accounted for significance in the overall test (Graham et al., 2004).

\section{Results}

\section{Environmental niche modeling}

The environmental niche modeling (ENM) results indicated good model performance (AUC>0.90). Isothermality and annual temperature range were the most contributive variables. In the Antillean entities, precipitation in the warmest quarter contributed most to the MaxEnt model in Mappia racemosa var. brachycarpa, while for M. racemosa var. racemosa annual temperature range was the variable with the greatest contribution to the model.

In the continental entities, precipitation in the wettest quarter showed a greater contribution to the distribution predicted in the MaxEnt model. Potential occurrence areas for $M$. racemosa var. racemosa and $M$. racemosa var. brachycarpa were identified in Florida, the Antilles, some areas in Mesoamerica and South America. For M. multiflora, areas of potential occurrence were identified mainly in Mesoamerica (Fig. 2).

The environmental niche models predicted well the documented geographic distribution of the different Mappia entities, as known by information of herbarium specimens and taxonomic revisions of the genus (Angulo et al., 2013). The climatic niches of the Antillean and continental species might not be ecologically interchangeable since they do not inter-predict each other (low niche overlap). On the other hand, a strong niche overlap between the Antillean entities was observed on the potential distribution, suggesting the entities might be ecologically interchangeable (Fig. 2).

\section{Ecological differentiation}

Evidence of niche divergence was detected for all taxa in the niche divergence/conservatism tests. The first three components explained over $80 \%$ of the observed divergence. 


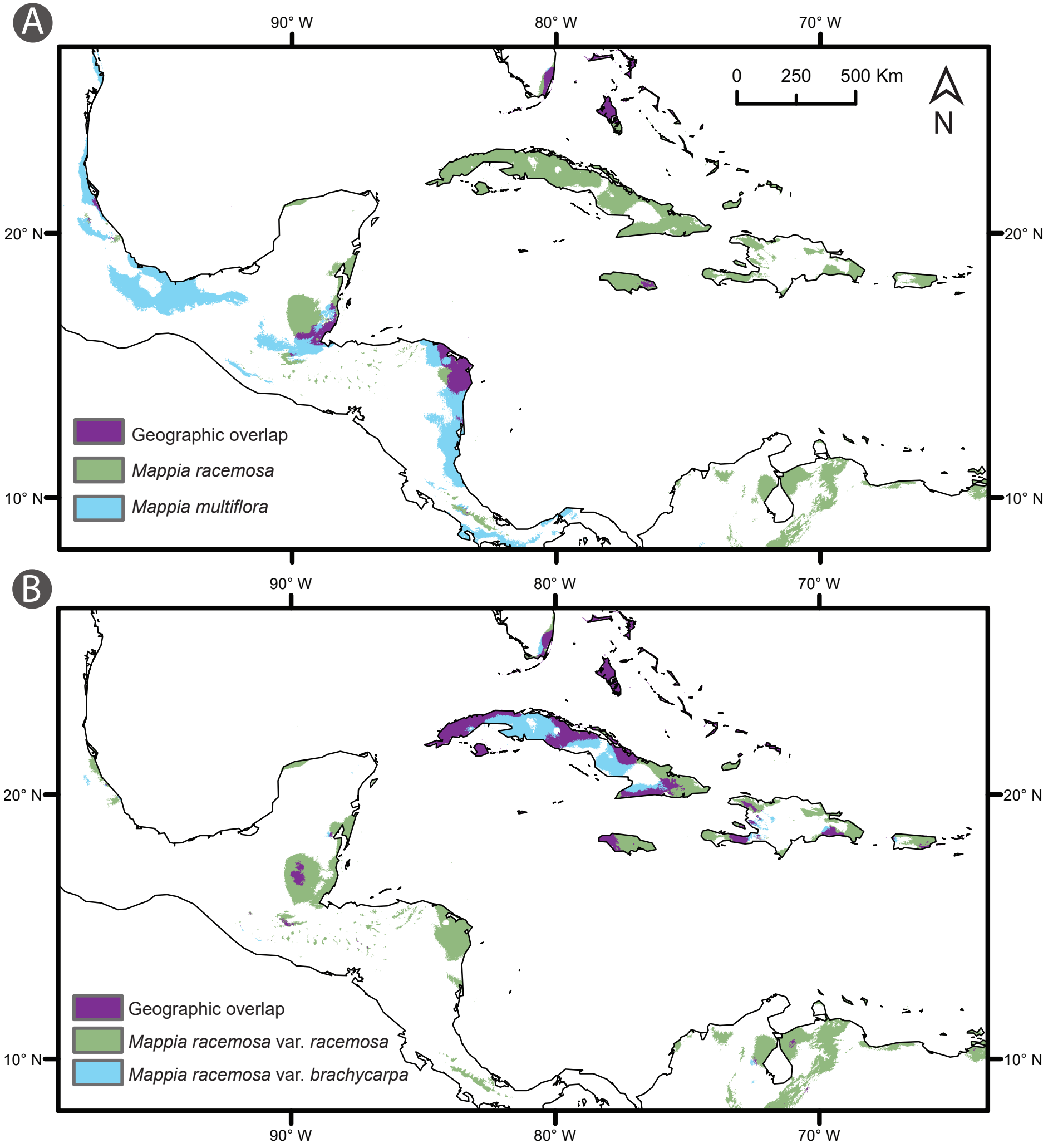

Figure 2: Ecological niche models of Mappia Jacq. entities. A. predictions of potential habitats for M. racemosa Jacq., M. multiflora Lundell, and geographic overlap. B. predictions of potential habitats for $M$. racemosa Jacq. var. brachycarpa Griseb., and M. racemosa Jacq. var. racemosa, and geographic overlap. 
High loadings were observed mainly for temperature related variables rather than precipitation, suggesting the former might be an important factor associated with the distribution of species. The first three axes that represent the largest explained variation show that Mappia multiflora and $M$. racemosa var. racemosa diverged in all niche axes, $M$. multiflora and $M$. racemosa var. brachycarpa diverged in two of the three, while $M$. racemosa var. racemosa and M. racemosa var. brachycarpa diverged in one of the three (Table 2).

The overall MANOVA showed statistically significant differences between the continental and Antillean entities (Mappia multiflora/M. racemosa var. racemosa, $\mathrm{F}=4.41$, $\mathrm{P}=0.02$; Mappia multiflora/M. racemosa var. brachycarpa, $\mathrm{F}=6.34, \mathrm{P}<0.01$ ), but no differences among the Antillean entities ( $M$. racemosa var. racemosa/M. racemosa var. brachycarpa, $\mathrm{F}=3.19, \mathrm{P}=0.06)$.

\section{Discussion}

In general, our results in both ecological niche analysis (environmental niche modeling and niche divergence/ conservatism tests) and multivariate analysis of variance (MANOVA) support previous phylogenetic study, where a continental (Mappia multiflora) and an Antillean clade (Mappia racemosa) were found (Angulo et al., 2013). Furthermore, at the infraspecific level our results reject Howard's hypothesis where two distinct entities are recognized (Howard, 1942). We discuss these results in detail below.

Environmental niche modeling and ecological differentiation

Levin $(2000,2003)$ stated that changes in the ecological attributes of populations are an important component of speciation in many flowering plant lineages, and such changes alone may result in the origin of species. In addition, Rissler and Apodaca (2007) stated that the extent of cross-lineage divergence varies in response to isolation, this being either geographic or environmental. In the environmental niche modeling analyses, the potential distribution of Mappia multiflora did not show any distribution in the Antillean region. However, M. racemosa distribution did predict few areas in the continent. Mappia multiflora and $M$. racemosa are found in areas with different climatic regimes, mainly related to temperature.

These potential distribution lead to the conclusion that niche divergence exists between both species supporting our previous results (Angulo et al., 2013). This trend toward a specialized niche is also observed in the multivariate niche evolution method that suggests niche divergence, in most PC axes. This multivariate method provides detailed information on niche divergence, as it is in closer agreement with the Hutchinsonian idea of the niche as a multidimensional hypervolume (Hutchinson, 1957), in which some axes will remain conserved while others diverge. Both environmental niche modeling and PC analysis suggested trends toward an adaptative divergence to local specialized niche between Mappia multiflora and Mappia racemosa. That is, ecological discontinuity between Mappia species is strongly influenced by environmental factors (most notably temperature), suggesting different climate selection pressures in each habitat. Hence, the results show that the continental and Caribbean populations have different ecological niches, despite sharing similar preferences: latitudes and vegetation, dry forest mainly on calcareous soils (Angulo, 2006). Although the other two species of the genus were not included in the analysis because of the low number of specimens, both occupy different ecological niches; $M$. longipes occurs at $1300 \mathrm{~m}$, while $M$. mexicana grows in lowlands near the limit of the tropical region. All cases suggest allopatric and adaptive ecological divergence.

The evolutionary divergence of the genus Mappia implies primarily an allopatric distribution, a body of salt water between the continental and the island species that interrupts the gene flow between both species. Secondly, an ecological divergence (climatic preference) where sympatric species exploit alternative ecological niches through cumulative morphological changes (Chase and Leibold, 2003).

The most important difference among infraspecific taxa of Mappia racemosa, the fruit with a fleshy mesocarp or not (Howard, 1942), is highly variable within Mappia species. For example, this variation in mesocarp consistency also occurs within individuals of Mappia multiflora growing in the Los Tuxtlas Biological Station in Veracruz (Angulo, 


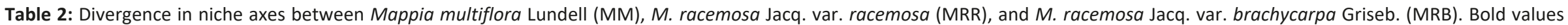

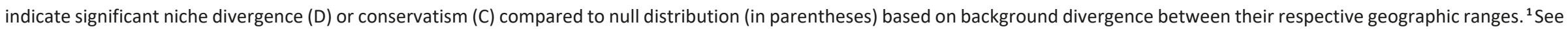
Table 1 for variable descriptions. Values in italics indicate opposite sign.

\begin{tabular}{|c|c|c|c|c|c|c|c|c|c|c|c|c|}
\hline \multirow{3}{*}{$\begin{array}{l}\text { Pairwise } \\
\text { comparison }\end{array}$} & \multicolumn{12}{|c|}{ Niche axes } \\
\hline & \multicolumn{2}{|c|}{ PC 1} & \multicolumn{2}{|c|}{ PC 2} & \multicolumn{2}{|c|}{ PC 3} & \multicolumn{2}{|c|}{ PC 4} & \multicolumn{2}{|c|}{ PC 5} & \multicolumn{2}{|c|}{ PC 6} \\
\hline & 1 vs. 2 & 2 vs. 1 & 1 vs. 2 & 2 vs. 1 & 1 vs. 2 & 2 vs. 1 & 1 vs. 2 & 2 vs. 1 & 1 vs. 2 & 2 vs. 1 & 1 vs. 2 & 2 vs. 1 \\
\hline \multirow[t]{2}{*}{ MM vs. MRR } & $0.70 \mathrm{D}$ & $0.70 \mathrm{D}$ & $1.62 \mathrm{D}$ & $1.62 \mathrm{D}$ & $0.81 \mathrm{D}$ & $0.81 \mathrm{D}$ & $0.10 \mathrm{C}$ & $0.10 \mathrm{C}$ & $0.32 \mathrm{C}$ & $0.32 \mathrm{C}$ & $1.26 \mathrm{D}$ & $1.26 \mathrm{D}$ \\
\hline & $(0.20,0.53)$ & $(0.11,0.51)$ & $(0.63,0.73)$ & $(1.03,1.56)$ & $(0.01,0.26)$ & $(0.44,0.82)$ & $(0.17,0.34)$ & $(0.18,0.68)$ & $(0.45,0.68)$ & $(0.92,1.38)$ & $(0.23,0.52)$ & $(0.44,1.16)$ \\
\hline \multirow[t]{2}{*}{ MM vs. MRB } & $0.26 \mathrm{D}$ & $0.26 \mathrm{C}$ & $1.47 \mathrm{D}$ & $1.47 \mathrm{D}$ & 0.35 & $0.35 \mathrm{C}$ & $0.66 \mathrm{D}$ & $0.66 \mathrm{D}$ & $0.89 \mathrm{D}$ & $0.89 \mathrm{D}$ & $1.30 \mathrm{D}$ & $1.30 \mathrm{D}$ \\
\hline & $(0.10,0.27)$ & $(0.16,0.56)$ & $(0.79,0.94)$ & $(0.26,0.79)$ & $(0.17,0.48)$ & $(0.24,0.62)$ & $(0.01,0.23)$ & $\begin{array}{l}(4.3 E- \\
05,0.42)\end{array}$ & $(0.01,0.20)$ & $\begin{array}{l}(5.15 E- \\
05,0.32)\end{array}$ & $(0.11,0.32)$ & $(0.03,0.45)$ \\
\hline \multirow[t]{2}{*}{ MRR vs. MRB } & $0.96 \mathrm{D}$ & $0.96 \mathrm{D}$ & $0.15 \mathrm{C}$ & $0.15 \mathrm{C}$ & 0.46 & 0.46 & $0.55 \mathrm{D}$ & $0.55 \mathrm{D}$ & $0.57 \mathrm{D}$ & $0.57 \mathrm{D}$ & $0.03 \mathrm{C}$ & $0.03 \mathrm{C}$ \\
\hline & $(0.002,0.27)$ & $(0.42,0.60)$ & $(0.74,0.84)$ & $(0.67,0.83)$ & $(0.34,0.62)$ & $(0.32,0.64)$ & $(0.31,0.48)$ & $\begin{array}{l}(1.59 \mathrm{E}- \\
05,0.12)\end{array}$ & $(0.21,0.44)$ & $(0.11,0.34)$ & $(0.78,1.06)$ & $(0.94,1.15)$ \\
\hline $\begin{array}{l}\text { \% variance } \\
\text { explained }\end{array}$ & 37.4 & & 25.9 & & 18.9 & & 9.1 & & 4.5 & & 2.6 & \\
\hline Eigenvalues & 3.368 & & 2.334 & & 1.704 & & 0.823 & & 0.411 & & 0.24 & \\
\hline \multirow[t]{2}{*}{$\begin{array}{l}\text { Variable } \\
\qquad \text { loadings }^{1}\end{array}$} & Bio 7 & & Bio 6 & & Bio 16 & & Bio 3 & & Bio 18 & & Bio 3 & \\
\hline & Bio 15 & & Bio 8 & & Bio 3 & & Bio 14 & & Bio 14 & & Bio 7 & \\
\hline $\begin{array}{l}\text { Biological } \\
\text { interpretation }\end{array}$ & Temp/Precip & & Temperature & & $\begin{array}{r}\text { Precip/ } \\
\text { Temp }\end{array}$ & & $\begin{array}{l}\text { Temp/ } \\
\text { Precip }\end{array}$ & & Precipitation & & Temperature & \\
\hline
\end{tabular}


2006). Furthermore, the sympatric spatial distribution of the infraspecific taxa of Mappia racemosa's island population (Antilles) greatly raises the possibility of gene flow among their populations, which could have reduced the evolutionary divergence.

This study gives an important signal about the ecological divergence between closely related species (Mappia multiflora and $M$. racemosa). Other studies incorporating physiological, ecological, and molecular markers with faster mutation rates, such as microsatellites or Single Nucleotide Polymorphisms (SNPs), are necessary to understand the complete evolutionary history of the genus.

\section{Author contributions}

RDS and DFA reviewed the literature and herbarium specimens and wrote the manuscript. DFA and IL performed the analyses. All authors reviewed the manuscript and approved of the final version.

\section{Funding}

This research was supported by the Centro de Investigación Cientifica de Yucatán, A.C. with funds allocated to the Unidad de Recursos Naturales.

\section{Acknowledgements}

We would like to thank the following herbaria and their curators: $\mathrm{BM}, \mathrm{CICY}, \mathrm{F}, \mathrm{G}, \mathrm{GH}, \mathrm{GOET}, \mathrm{K}$, LL, MA, MEXU, MO, NY, $P$, US, TEX, and XAL. The authors would like to thank Eduardo Ruiz Sanchez and Tania Hernández for suggestions and comments, and Silvia Hernández-Aguilar and Lilia Lorena Can for their herbarium work.

\section{Literature cited}

Anderson, R. P., M. Gómez-Laverde and A. T. Peterson. 2002a. Geographical distributions of spiny pocket mice in South America: Insights from predictive models. Global Ecology and Biogeography 11(2): 131-141. DOI: https://doi. org/10.1046/j.1466-822X.2002.00275.x

Anderson, R. P., A. T. Peterson and M. Gómez-Laverde. 2002b. Using niche-based GIS modeling to test geographic predictions of competitive exclusion and competitive release in South American pocket mice. Oikos 98(1): 3-16. DOI: https://doi. org/10.1034/j.1600-0706.2002.t01-1-980116.x
Angulo, D. F. 2006. Análisis filogenético y sistemática del género Mappia (Icacinaceae) en el Neotrópico a partir de caracteres morfo-anatómicos. Tesis de licenciatura. Instituto Tecnológico de Conkal. Conkal, Yucatán, México. $75 \mathrm{pp}$.

Angulo, D. F., V. Sosa and J. G. García-Franco. 2014a. Floral movement: Stamen motion in Berberis trifoliolata. Botanical Sciences 92(1): 141-144. DOI: https://doi.org/10.17129/ botsci.46

Angulo, D. F., L. D. Amarilla and V. Sosa. 2014b. Incipient speciation in the Chihuahuan Desert shrub Berberis trifoliolata under divergent climate scenarios. Botany 92(3): 195-201. DOI: https://doi.org/10.1139/cjb-2013-0213

Angulo, D. F., R. Duno de Stefano and G. W. Stull. 2013. Systematics of Mappia (Icacinaceae), an endemic genus of tropical America. Phytotaxa 116(1): 1-18. DOI: https://doi. org/10.11646/phytotaxa.116.1.1

Baehni, C. 1936. Revision des genres Neoleretia, Mappia et Humirianthera. Candollea 7: 167-184.

Barnosky, A. D. 2005. Effects of Quaternary climatic change on speciation in mammals. Journal of Mammalian Evolution 12: 247-264. DOI: https://doi.org/10.1007/s10914-0054858-8

Barraclough, T. G., A. P. Vogler and P. H. Harvey. 1998. Revealing the factors that promote speciation. Philosophical Transactions of the Royal Society B: Biological Sciences 353: 241-249. DOI: https://doi.org/10.1098/rstb.1998.0206

Chase, J. M. and M. A. Leibold. 2003. Ecological Niches: Linking Classical and Contemporary Approaches. University of Chicago Press. Chicago, USA. 212 pp.

Duno de Stefano, R. and D. F. Angulo. 2010. Icacinaceae. In: Greuter, W. and R. Rodríguez (eds.). Flora de la República de Cuba, serie A, plantas vasculares. Gantner, Ruggell, Liechtenstein. fascículo 16(4). Pp. 13.

Fielding, A. H. and J. F. Bell. 1997. A review of methods for the assessment of prediction errors in conservation presence/ absence models. Environmental Conservation 24(1): 38-49. DOI: https://doi.org/10.1017/S0376892997000088

Funk, D. J., S. P. Egan and P. Nosil. 2011. Isolation by adaptation in Neochlamisus leaf beetles: host-related selection promotes neutral genomic divergence. Molecular Ecology 20: 4671-4682. DOI: https://doi.org/10.1111/j.1365294X.2011.05311.x 
Gaubert, P., M. Papes and A. T. Peterson. 2006. Natural history collections and the conservation of poorly known taxa: Ecological niche modeling in central African rainforest genets (Genetta spp.). Biological Conservation 130(1): 10611. DOI: https://doi.org/10.1016/j.biocon.2005.12.006

GBIF. 2019. GBIF Secretariat: GBIF Backbone Taxonomy. Checklist dataset. https://doi.org/10.15468/39omei Accessed via https://www.gbif.org/species/3169093 (consulted January, 2020).

Graham, C. H., S. R. Ron, J. C. Santos, C. J. Schneider and C. Moritz. 2004. Integrating phylogenetics and environmental niche models to explore speciation mechanisms in dendrobatid frogs. Evolution 58(8): 1781-1793. DOI: https://doi. org/10.1111/j.0014-3820.2004.tb00461.x

Hammer, Ф., D. A. T. Harper and P. D. Ryan. 2001. PAST: Paleontological Statistics Software Package for Education and Data Analysis. Palaeontologia Electronica 4(1): 9 pp. http://palaeo-electronica.org/2001_1/past/issue1_01.htm (consulted January, 2019).

Hengl, T., J. Mendes de Jesus, G. B. M. Heuvelink, M. Ruiperez Gonzalez, M. Kilibarda, A. Blagotić, W. Shangguan, M. N. Wright, X. Geng, B. Bauer-Marschallinger, M. A. Guevara, R. Vargas, R. A. MacMillan, N. H. Batjes, J. G. B. Leenaars, E. Ribeiro, I. Wheeler, S. Mantel and B. Kempen. 2017. SoilGrids250m: global gridded soil information based on machine learning. PLoS ONE 12(2): e0169748. DOI: https:// doi.org/10.1371/journal.pone.0169748

Hernandez, P. A., C. H. Graham, L. L. Master and D. L. Albert. 2006. The effect of sample size and species characteristics on performance of different species distribution modeling methods. Ecography 29(5): 773-785. DOI: https://doi. org/10.1111/j.0906-7590.2006.04700.x

Hijmans, R. J., S. Cameron, J. Parra, P. Jones and A. Jarvis. 2005. Very high resolution interpolated climate surfaces for global land areas. International Journal of Climatology 25(15): 1965-1978. DOI: https://doi.org/10.1002/joc.1276

Howard, R. A. 1942. Studies of the Icacinaceae II. Humirianthera, Leretia, Mappia and Nothapodytes, valid genera of the Icacineae. Journal of the Arnold Arboretum 23: 55-78.

Hua, X. and J. J. Wiens. 2013. How Does Climate Influence Speciation? American Naturalist 182(1): 1-12. DOI: https:// doi.org/10.1086/670690
Hutchinson, G. E. 1957. Concluding remarks. Cold Spring Harbor Symposia on Quantitative Biology 22: 415-427.

IBM. 2010. IBM SPSS Statistics for Windows, Version 19.0. IBM Corp. Armonk, USA

Jansson, R. and M. Dynesius. 2002. The fate of clades in a world of recurrent climatic change: Milankovitch oscillations and evolution. The Annual Review of Ecology, Evolution, and Systematics 33: 741-777. DOI: https://doi.org/10.1146/ annurev.ecolsys.33.010802.150520

Johnson, N. K. and C. Cicero. 2002. The role of ecologic diversification in sibling speciation of Empidonax flycatchers (Tyrannidae): multigene evidence from mtDNA. Molecular Ecology 11(10): 2065-2081. DOI: https://doi.org/10.1046/ j.1365-294x.2002.01588.x

Kozak, K. H. and J. J. Wiens. 2007. Climatic zonation drives latitudinal variation in speciation mechanisms. Proceedings of the Royal Society of London. Series B 274: 2995-3003. DOI: https://doi.org/10.1098/rspb.2007.1106

Levin, D. A. 2000. The origin, expansion, and demise of plant species. Oxford University Press. New York, USA. 230 pp.

Levin, D. A. 2003. The ecological transition in speciation. New Phytologist 161(1): 91-96. DOI: https://doi.org/10.1046/ j.1469-8137.2003.00921.x

Lobo, J. M., A. Jiménez-Valverde and R. Real. 2008. AUC: a misleading measure of the performance of predictive distribution models. Global Ecology and Biogeography 17(2): 145-151. DOI: https://doi.org/10.1111/j.14668238.2007.00358.x

Longino, J. T., J. Coddington and R. K. Colwell. 2002. The ant fauna of a tropical rain forest: estimating species richness three different ways. Ecology 83(3): 689-702. DOI: https://doi. org/10.1890/0012-9658(2002)083[0689:TAFOAT]2.0.CO;2

Lowry, D. B., R. C. Rockwood and J. H. Willis. 2008. Ecological reproductive isolation of coast and inland races of Mimulus guttatus. Evolution 62(9): 2196-2214. DOI: https://doi. org/10.1111/j.1558-5646.2008.00457.x

Lundell, C. L. 1942. Studies of American spermatophytes-II. Contributions from the University of Michigan Herbarium 7: 1-54.

Martínez-Gordillo, D., O. Rojas-Soto and A. Espinosa de los Monteros. 2010. Ecological niche modelling as an exploratory tool for identifying species limits: an example 
based on Mexican muroid rodents. The Journal of Evolutionary Biology 23(2): 259-270. DOI: https://doi. org/10.1111/j.1420-9101.2009.01897.x

Martınez-Meyer, E., A. T. Peterson and A. G. Navarro-Sigüenza. 2004. Evolution of seasonal ecological niches in the Passerina buntings (Aves: Cardinalidae). Proceedings of the Royal Society B: Biological Sciences 271(1544): 1151-1157. DOI: https://doi.org/10.1098/rspb.2003.2564

McCormack, J. E., A. J. Zellmer and L. L. Knowles. 2010. Does niche divergence accompany allopatric divergence in Aphelocoma jays as predicted under ecological speciation? Insights from tests with niche models. Evolution 64(5): 1231-1244. DOI: https://doi.org/10.1111/j.1558-5646.2009.00900.x

Mittelbach, G. G., D. W. Schemske, H. V. Cornell, A. P. Allen, J. M. Brown, M. B. Bush, S. P. Harrison, A. H. Hurlbert, N. Knowlton, H. A. Lessios, C. M. McCain, A. R. McCune, L. A. McDade, M. A. McPeek, T. J. Near, T. D. Price, R. E. Ricklefs, K. Roy, D. F. Sax, D. Schluter, J. M. Sobel and M. Turelli. 2007. Evolution and the latitudinal diversity gradient: speciation, extinction and biogeography. Ecology Letters 10(4): 315-331. DOI: https://doi.org/10.1111/j.1461-0248.2007.01020.x

Murienne, J., E. Guilbert and P. Grandcolas. 2009. Species' diversity in the New Caledonian endemic genera Cephalidiosus and Nobarnus (Insecta: Heteroptera: Tingidae), and approach using phylogeny and species' distribution modelling. Biological Journal of the Linnean Society 97(1): 177-184. DOI: https://doi.org/10.1111/j.1095-8312.2008.01184.x

Nakazato, T. D., L. Warren and L. C. Moyle. 2010. Ecological and geographic modes of species divergence in wild tomatoes. American Journal of Botany 97(4): 680-693. DOI: https:// doi.org/10.3732/ajb.0900216

Peterson, A. T. 2003. Predicting the Geography of Species' Invasions via Ecological Niche Modeling. The Quarterly Review of Biology 78(4): 419-433. DOI: https://doi. org/10.1086/378926

Peterson, A. T. 2007. Why not WhyWhere: the need for more complex models of simpler environmental spaces. Ecological Modelling 203(3-4): 527-530. DOI: https://doi. org/10.1016/j.ecolmodel.2006.12.023

Peterson, A. T, M. Papeş and M. Eaton. 2007. Transferability and model evaluation in ecological niche modeling: a comparison of GARP and MaxEnt. Ecography 30(4): 550-560.
DOI: https://doi.org/10.1111/j.0906-7590.2007.05102.x

Peterson, M. L., K. J. Rice and J. P. Sexton. 2013. Niche partitioning between close relatives suggests trade-offs between adaptation to local environments and competition. Ecology and Evolution 3(3): 512-522. DOI: https://doi.org/10.1002/ ece3.462

Phillips, S. J., R. P. Anderson and R. E. Shapire. 2006. Maximum entropy modelling of species geographic distributions. Ecological Modelling 190(3-4): 231-259. DOI: https://doi. org/10.1016/j.ecolmodel.2005.03.026

R Core Team. 2017. R: A language and environment for statistical computing. R Foundation for Statistical Computing. Vienna, Austria. https://www.R-project.org/ (consulted January, 2017).

Rabinowitz, D. 1981. Seven forms of rarity. In: Synge, H. (ed.). The biological aspects of rare plants conservation. Wiley, New York. USA. Pp. 205-217.

REMIB. 2019. Red mundial de información sobre biodiversidad. Comisión Nacional para el Conocimiento y Uso de la Biodiversidad. México. http://www.conabio.gob.mx/remib (consulted January, 2019).

Rissler, L.J.andJ.J.Apodaca.2007. Addingmoreecologyintospecies delimitation: ecological niche models and phylogeography help define cryptic species in the black salamander (Aneides flavipunctatus). Systematic Biology 56(6): 924-942. DOI: https://doi.org/10.1080/10635150701703063

Robinson, B. L. and J. M. Greenman. 1895. New and noteworthy plants chiefly from Oaxaca collected by Messrs. C. G. Pringle, L. C. Smith and E. W. Nelson. American Journal of Science, and Arts, ser. 3, 50: 150-168.

Schneider, C. J. and C. Moritz. 1998. Comparative phylogeography and the history of endemic vertebrates in the wet tropics rainforests of Australia. Molecular Ecology 7(4): 487-498. DOI: https://doi.org/10.1046/j.1365-294x.1998.00334.x

Sites, J. W. and J. C. Marshall. 2003. Delimiting species: a Renaissance issue in systematic biology. Trends in Ecology and Evolution 18(9): 462-470. DOI: https://doi.org/10.1016/ S0169-5347(03)00184-8

Sites, J. W. and J. C. Marshall. 2004. Operational criteria for delimiting species. Annual Review of Ecology, Evolution, and Systematics 35: 199-227. DOI: https://doi.org/10.1146/ annurev.ecolsys.35.112202.130128 
Sobel, J. M., G. F. Chen, L. R. Watt and D. W. Schemske. 2010. The biology of speciation. Evolution 64(2): 295-315. DOI: https://doi.org/10.1111/j.1558-5646.2009.00877.x

StataCorp. 2009. Stata Statistical Software: Release 11. StataCorp. LP. College Station, USA.

Thiers, B. 2020. Index Herbariorum: A global directory of public herbaria and associated staff. New York Botanical Garden's Virtual Herbarium. New York, USA. http://sweetgum.nybg. org/science/ih/ (consulted January, 2020).

Vanden Broeck, A., W. Van Landuyt, K. Cox, L. De Bruyn, R. Gyselings, G. Oostermeijer, B. Valentin, G. Bozic, B. Dolinar, Z. Illyes and J. Mergeay. 2014. High levels of effective longdistance dispersal may blur ecotypic divergence in a rare terrestrial orchid. BMC Ecology 14: 20. DOI: https://doi. org/10.1186/1472-6785-14-20

van Proosdij, A. S. J., M. S. M. Sosef, J. J. Wieringa and N. Raes. 2016. Minimum required number of specimen records to develop accurate species distribution models. Ecography 39: 542-552. DOI: https://doi.org/10.1111/ecog.01509

Warren, D. L. and S. N. Seifert. 2011. Ecological niche modeling in Maxent: the importance of model complexity and the performance of model selection criteria.
Ecological Applications 21(2): 335-342. DOI: https://doi. org/10.1890/10-1171.1

Wiens, J. J., D. D. Ackerly, A. P. Allen, B. L. Anacker, L. B. Buckley, H. V. Cornell, E. I. Damschen, T. Jonathan Davies, J. A. Grytnes, S. P. Harrison, B. A. Hawkins, R. D. Holt, C. M. McCain and P. R. Stephens. 2010. Niche conservatism as an emerging principle in ecology and conservation biology. Ecology Letters 13(10): 1310-1324. DOI: https://doi.org/10.1111/ j.1461-0248.2010.01515.x

Wiens, J. J. and C. H. Graham. 2005. Niche conservatism: integrating evolution, ecology, and conservation biology. Annual Review of Ecology, Evolution, and Systematics 36: 519-539. DOI: https://doi.org/10.1146/annurev. ecolsys.36.102803.095431

Wiens, J. J. and T. A. Penkrot. 2002. Delimiting species using DNA and morphological variation and discordant species limits in spiny lizards (Sceloporus). Systematic Biology 51(1): 69-91. DOI: https://doi.org/10.1080/106351502753475880

Wortley, A. H., P. J. Rudall, D. J. Harris and R. W. Scotland. 2005. How much data are needed to resolve a difficult phylogeny? Case Study in Lamiales. Systematic Biology 54(5): 697-709. DOI: https://doi.org/10.1080/10635150500221028 